\title{
Self reported prevalence and treatment of sleep disorders in Austria
}

\author{
A Schmeiser-Rieder, G Kapfhammer, J Bolitschek, B Holzinger, A Skrobal, M Kunze, \\ H Lechner, B Saletu, J Zeitlhofer
}

Sleep disorders pose a very common problem which increases with age. The impact of sleep disorders and their treatment (hypnotics are among the most widely prescribed drugs) merits particular attention in western society. ${ }^{1}$ This report aims to present some first data from a study on sleep disturbances in Austria, where, in the near future, a third of the population will be older than 60 years. The study was carried out by the Institute of Social Medicine, University of Vienna and the Austrian Sleep Research Association (ASRA).

Method: In March 1993, a representative sample of the Austrian population aged between 14 and 69 years was investigated for sleep disorders with the aid of a questionnaire. The sample was taken by random sampling from electoral rolls. Randomising and face to face interviews were carried out by the Austrian GALLUP-Institute. The GALLUP-Institute selected 150 sample points with 10 addresses in each. The response rate of fully completed

Prevalence and duration of self reported sleep disorders (values, \%)

\begin{tabular}{|c|c|c|c|c|}
\hline Characteristics & $\begin{array}{l}\text { Sleep } \\
\text { disorders } \\
<1 \text { year }\end{array}$ & $\begin{array}{l}\text { Sleep } \\
\text { disorders } \\
\geq 1 y\end{array}$ & $\begin{array}{l}\text { Sleep } \\
\text { disorders } \\
\text { all }\end{array}$ & $\begin{array}{l}\text { No sleep disorders } \\
\text { reported }\end{array}$ \\
\hline $\begin{array}{l}\text { Sex } \\
\text { Male } \\
\text { Female }\end{array}$ & $\begin{array}{l}3 \\
4\end{array}$ & $\begin{array}{l}21 \\
23\end{array}$ & $\begin{array}{l}24 \\
27\end{array}$ & $\begin{array}{l}76 \\
72\end{array}$ \\
\hline $\begin{array}{l}\text { Age }(y): \\
\quad-30 \\
31-50 \\
>50\end{array}$ & $\begin{array}{l}5 \\
3 \\
5\end{array}$ & $\begin{array}{r}8 \\
18 \\
37\end{array}$ & $\begin{array}{l}13 \\
21 \\
42\end{array}$ & $\begin{array}{l}87 \\
79 \\
58\end{array}$ \\
\hline $\begin{array}{l}\text { Occupation: } \\
\text { Professional } \\
\text { Civil servant } \\
\text { Manual worker } \\
\text { Farmer } \\
\text { Student } \\
\text { Housewife } \\
\text { Pensioner }\end{array}$ & $\begin{array}{l}2 \\
5 \\
4 \\
0 \\
4 \\
5 \\
5\end{array}$ & $\begin{array}{l}21 \\
10 \\
12 \\
19 \\
10 \\
20 \\
37\end{array}$ & $\begin{array}{l}23 \\
15 \\
16 \\
19 \\
14 \\
25 \\
42\end{array}$ & $\begin{array}{l}77 \\
85 \\
72 \\
81 \\
86 \\
75 \\
58\end{array}$ \\
\hline $\begin{array}{l}\text { Income: } \\
\text {-US\$ } 1.000 \text { (ATS } \\
\text { 12.500) } \\
\text {-US\$ } 1.600 \text { (ATS }\end{array}$ & $\begin{array}{l}3 \\
3\end{array}$ & 30 & $\begin{array}{l}33 \\
24\end{array}$ & $\begin{array}{l}63 \\
73\end{array}$ \\
\hline $\begin{array}{l}20.000) \\
\text {-US\$2.400 (ATS }\end{array}$ & 1 & 14 & 15 & 85 \\
\hline >US\$ 2.400 & 3 & 21 & 24 & 74 \\
\hline $\begin{array}{l}\text { Shift work: } \\
\text { Yes } \\
\text { No }\end{array}$ & $\begin{array}{l}0 \\
4\end{array}$ & $\begin{array}{l}24 \\
17\end{array}$ & $\begin{array}{l}24 \\
21\end{array}$ & $\begin{array}{l}76 \\
78\end{array}$ \\
\hline $\begin{array}{l}\text { Environment: } \\
-5000 \text { inhabitants } \\
-50000 \text { inhabitants } \\
>50000 \text { inhabitants }\end{array}$ & $\begin{array}{l}3 \\
7 \\
5\end{array}$ & $\begin{array}{l}16 \\
27 \\
19\end{array}$ & $\begin{array}{l}19 \\
24 \\
24\end{array}$ & $\begin{array}{l}81 \\
66 \\
75\end{array}$ \\
\hline All & 4 & 21 & 25 & 74 \\
\hline
\end{tabular}

questionnaires was $70 \%$. This data base, which includes at least 1000 Austrians, is calculated to be representative of the Austrian general population in terms of age, sex, and social class. Control of response and a computer assisted plausibility check were performed for all the interviews. The final questionnaire which was used was prepared and compiled by the ASRA and is based on questionnaires from other comparable studies ${ }^{2}$ and questionnaires used by sleep disorder clinics, for example at Stanford University. ${ }^{3}$ The prevalence of drug use is based on reports of sleeping drug use (twice a week or more) in the four weeks before the respective interviews were carried out. Comparisons of percentages were calculated with the $\chi^{2}$ test. The results were considered statistically significant at $\mathrm{p}<0 \cdot 05$.

Results: Twenty five per cent of the sample reported sleep disorders of some sort; among these, $84 \%$ had lasted longer than one year. The highest prevalences of sleep disorders were observed in pensioners $(42 \%, \mathrm{p}<0.0005)$, people aged over 50 years $(42 \%, \mathrm{p}<0.0005)$, and people on low income $(33 \%, \mathrm{p}<0.001)$. The highest proportions of long term sleep disorders were also seen in these groups (table). Three per cent of the sample had taken sleeping drugs on prescription (mostly benzodiazepines): percentages grouped according to age were $<30$ years, $0 \% ; 30-50$ years, $1 \%$; and $>50$ years, $9 \%(p<0 \cdot 00000)$. One per cent of the sample reported taking over the counter (OTC) drugs (valerian products). Most drugs were consumed in those groups with the highest prevalence of sleep disorders: $10 \%$ in pensioners and $9 \%$ in people older than 50 years and people on a low income $(p<0.0001)$. One per cent of men and $5 \%$ of women reported taking drugs on prescription $(p<0.001)$. The consumption of sleeping drugs increased with the duration of sleep disorders (for sleep disorders lasting $<1$ year, $2 \%$ were taking prescription drugs and $2 \%$ OTC drugs; for disorders lasting $>1$ year, $13 \%$ were on prescription drugs and $5 \%$ on OTC drugs). Half of the drug users had been taking these drugs since the age of 60 (women:men, 3:1). Of the people with problems of daily prolonged sleep latency $(7 \%), 27 \%$ reported drug intake, compared with $9 \%$ of those with disrupted sleep 
(28\%; frequency: >once a month). With regard to the reasons for sleep disorders, "personal problems" were blamed most $(19 \%)$, followed by "events of the day" (15\%), "physical illness" (14\%), "problems at work" (9\%), "looking after children and the sick" (8\%), and "environmental noise" (7\%). Subjects with long term sleep disorders more frequently recognized the cause of their sleep disorders, which was often "physical illness" $(79 \%)$ and was commonest in older adults.

Discussion: A quarter of the Austrian population acknowledges their sleeping patterns as abnormal. In various studies, prevalence rates of sleep disorders are reported to be between $20-30 \%$ in industrial countries. ${ }^{4}$ The study results suggest that chronic sleep disorders characterize those in the general population. Sleep disruption is the most frequent problem, but prolonged sleep latency seems to be the most commonly treated one. In agreement with other published reports, ${ }^{25}$ the prevalence of sleep disorders and consumption of sleeping drugs are strongly influenced by increasing age. In our study, there was a strong association between sleep disorders and low income. The low income group is largely made up of pensioners and women. Insomnia and hyposomnia are often reported by women in the climacteric years and in our study drug intake among women increases considerably with age in comparison to men.

Although normal aging can cause sleep disorders there are many factors that cause insomnia. ${ }^{5}$ Psychosocial problems and physical illness are the most common self reported causes for sleep disorders in our study, but only one third of these people had consulted a physician because of their sleep disorders. If doctors were informed earlier these problems might be diagnosed and individual pharmacological or non-pharmacological strategies could be worked out at an early stage. This is an important point because of the high prevalence of chronic sleep disorders.

At present, most patients with sleep disorders remain undiagnosed and untreated. ${ }^{1}$ Because of our aging population it is necessary to develop long range plans for dealing with sleep disorders, drugs, research, and prevention.

1 Shapiro C, Dement W. Impact and epidemiology of sleep disorders. BMF 1993:306:1604-7.

2 Hohagen F, Graßhoff U, Schramm E, Ellringmann D, Riemann $D$, Weyerer $S$, Berger $M$. Häufigkeit von Schlafstörungen in der allgemeinärztlichen Praxis. Prax Klin Verhaltensmed Rehab 1991;15:177-82.

3 Douglas A, Bornstein R, Nino-Murcia G. SDQ sleep disorders questionnaire, 1992, University of Michigan, USA

4 Hoijak G, Rüther E, Hauri PJ. Insomnien. In: Berger M ed. Handbuch des normalen und gestörten Schlafs. New York, Heidelberg: Springer, 1992;67-119.

5 Johnston E. Sleep poblems in the elderly. Fournal of the American Academy of Nurse Practitioners. 1994;6:161-6. 